\title{
Investing in commonly-held resources for inclusive and sustainable development Lessons from Guatemala, Mexico, Nepal and Namibia
}

\section{Key messages}

- Investment in commons comes primarily from donors, governments and communities, but private sector investment is increasing.

- Commons-based investment readiness is conditional on the level of assurance stakeholders have that the obligations of each party will be met. Investment readiness develops over time and in stages, as levels of assurance increase.

- Each sector has specific roles and responsibilities for mitigating risk.

- Community rights have fostered investment that recognizes the social character of commons ownership and delivers environmental and social returns, as well as profits.

- There is a need for additional research on the origins, mechanisms, volume and direction of investment in community-managed resources that can help communities and investors alike better understand their options.

\section{Introduction}

Local communities and indigenous peoples manage a significant portion of the world's remaining forests, pastures and fisheries as common property resources (Wily 2018). Devolving ownership, use and exclusionary rights to communities can, in many circumstances, provide incentives for them to manage resources in ways that facilitate sustainable management outcomes as well as greater equity in benefits distribution (Baynes et al. 2015). However, our understanding of who is investing in community-held resources following rights devolution and of how investment patterns evolve over time is fragmentary. We address this knowledge gap by exploring the pathways that have emerged to deliver investment in common property resources in Guatemala, Mexico, Nepal and Namibia.

Centre for International Forestry Research

2 Forest Action, Nepal

\section{Background}

When rights are devolved, the community as a whole is recognized as the rights holder and new or existing community institutions are empowered to govern the commons (Cronkleton et al. 2011; Ambrose-Oji et al. 2015). Where rights to forests are devolved, for instance, community forest institutions (CFIs) emerge, typically consisting of community user groups that carry out forest governance functions together with one or more community forest enterprises (CFEs) designed to capture the monetary values of forest commons (Bray and Merino 2002). CFEs operate as social enterprises, which differ from for-profit enterprises in that their profits are "retained in their organizations and/or community either as direct services or as grants to the targeted population" (Foundjem-Tita et al. 2019, 5). CFEs are viewed as a type of social innovation (Kluvánková et al. 2018), where social innovation is defined as "...the reconfiguring of social practices, in response to societal challenges, which seeks to enhance outcomes on societal well-being and necessarily includes the engagement of civil society actors" (Polman et al. 2017, 12).

Lack of financial capital often limits CFI growth and success. The concept of investment readiness has emerged as a tool for guiding policies to reduce barriers to investments in enterprises (Mason and Kwok 2010). Investment readiness here is understood as the ability of CFI managers to be aware of the needs of investors and to address them by providing sufficient information and developing credibility and trust such that investors will provide financing (Fellnhofer 2015).

Creating investment-ready CFIs requires reducing risks and transaction costs. Four key conditions can reduce risks and provide investors with the assurances they need to invest in CFIs: 1) clear, secure and sufficiently broad rights (Lawry et al. 2017), 2) relations of trust and strong social networks within communities and between communities and external actors (Baynes et al. 2015), 3) clear and enforceable rules and procedures governing forests and associated enterprises (Dasgupta 2005), and 4) sufficient technological, negotiation and management capacity within the community (Hewitt and Castro Delgadillo 2009). 
"The enabling investment creates the public goods, which in turn enable asset investments to create private assets. These private assets... are the assets formed by the rights-holders themselves: in companies, private savings, physical infrastructure and improved health and education" (Elson 2012, 27)

Enabling investments, such as policies that clarify rights and encourage transparency and accountability, and programs that build monitoring, enforcement, administrative and technical capacities, can reduce risks sufficiently to attract external financing for asset investments (Elson 2012). Local-level community organizations can form associations to increase their effectiveness at shaping the regulatory context so as to reduce risk and support financing for communities (Paudel et al. 2012).

Based on the concepts discussed above, we developed a provisional theory of change (TOC) (Figure 1) to guide our study of investments following rights devolution. Our TOC posits a pathway by which community rights devolution leads to investments and resulting social and environmental impacts. In this paper we seek to unpack the investment 'black boxes' depicted in the TOC diagram.

We frame our analysis around three propositions:

Proposition 1: Barriers to investments in CFls are not insurmountable and such investments do take place subsequent to rights devolution.
Proposition 2: Investment readiness of CFIs requires that prospective investors and investees have assurance that the obligations of each party will be honored. Each sector (i.e. public, civil society, private) takes on specific roles and responsibilities for mitigating risk.

Proposition 3: Community rights devolution has fostered investments by CFIs that deliver environmental and social returns, as well as profits.

\section{Methods}

\begin{tabular}{ll}
\hline Box 1 - Country and type of commons management \\
\hline Guatemala & Community Forest Concessions (forest) \\
Mexico & Ejidos and indigenous communities (forest) \\
Nepal & Community Forest User Groups (forest) \\
Namibia & Wildlife Conservancies (wildlife) \\
\hline
\end{tabular}

We used a comparative case study approach to evaluate patterns in investment sources, mechanisms, target sectors, and expected and realized returns or benefits within and across the countries included in the study. Guatemala, Mexico and Nepal have devolved forest rights to communities, while Namibia has devolved wildlife rights. The type of commons management in each country studied is listed in Box 1.

\begin{tabular}{|l|l|l|}
\multicolumn{1}{|c|}{ Context } & $\begin{array}{c}\text { Rights devolution/ formation of } \\
\text { community forest institutions }\end{array}$ \\
- Poverty & Weak governance \\
- Few livelihood options & Regraded forests
\end{tabular} \mid $\begin{aligned} & \text { Recognition of community rights to forests } \\
& \text { - Award and registration of title or certificate } \\
& \text { - Formation of community institution to receive title } \\
& \text { - Demarcation of community boundaries }\end{aligned}$

Inputs and Intervention

Formation of community institution to receive title marcation of community boundaries

\section{Barriers to investment in CFIs}

- Insufficiently broad rights (for example, commercial rights to non-timber forest products, but not timber)

- Community skeptical of outside investment

- Weak community capacity to manage commercial partnerships

- Community-held lands cannot be used as collateral

- Fear of traditional values eroding with market exposure

- Tension between social equity, environmental benefits and maximizing profits

-

\section{Investments in building capacity of community forest institutions}

\section{Changes in perceptions of risks and assurances}

- Tenure perceived as secure

- Rules exist, are broadly understood, and are enforced

- Increased confidence that agreements will be kept

- Increased ability to negotiate effectively with external actors

Investments in and by community forest enterprises

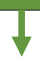

Positive environmental, social and financial returns

Enhanced forest conditions, more livelihood options, community infrastructure improvements, CFls financially viable
Intermediate outcomes

Outcomes

Assumptions

Assumptions

Impact 


\section{Results}

\section{Rights devolution overview}

In Guatemala, community concession contracts, which are legal agreements between the state and an organized group of people living in local communities, are a key element of forest rights devolution. Provisions to implement community forest concessions were introduced in 1994 and modified in 1998. The 1996 Peace Accord negotiations guaranteed community members' rights to resources in protected areas. Through 25-year contracts, concessionaire members have rights to manage and extract timber and non-timber forest products and to implement ecotourism activities in protected areas. Community access and settlement rights are granted only on the condition that high-value timber species be regulated and certified (Radachowsky et al. 2012).
In Mexico, community land rights devolution began with the revolution in the early 1920s (Bray and Merino 2002). Two types of community-based tenure regimes and forms of common pool resource management now exist — those based on indigenous communities and ejidos. The management and tenure regimes of indigenous communities are based on the recognition of customary rights while those of ejidos are based on a tenure form that emerged from agrarian reforms. Roughly half of Mexico's land area has been formally recognized as ejidos or indigenous community lands, and approximately 9000 communities have forests on their lands (INEGI 1997). In 2017, more than 2134 ejidos

and communities were reported to have forest management permits (Carrillo-Anzures et al. 2017).

Forest management in Nepal progressed gradually toward community-based arrangements, culminating in the Forest Act of 1993, which legalized diverse forms of community-based forest management, and recognized CFls as self-governing, perpetual and corporate institutions that could acquire, possess, transfer and manage movable or immovable property. As of 2017, Nepal had 22,266 community forests, involving 2.9 million households and covering roughly 22.37 million ha (Bhandari et al. 2019).

In 1996, Namibia institutionalized community-based natural resource management (CBNRM). Under this tenure reform, communal area residents can form a common property institution called a conservancy to manage, use and benefit from wildlife and other natural resources on their traditional lands (Naidoo et al. 2016). To register a conservancy, residents must develop resource management plans, register for membership, and set up a conservancy management committee and constitution. In 2017, Namibia had 83 registered conservancies covering roughly 163,000 sq km (MET/NACSO 2018).

\section{Investments following rights devolution}

The emergence of clearer and stronger local rights to resources following rights devolution in each of the four country cases catalyzed the public and private investments summed up in Table 1.

Table 1. Investments subsequent to rights devolution.

\begin{tabular}{|c|c|c|c|c|}
\hline & Guatemala & Mexico & Nepal & Namibia \\
\hline Donors & $\begin{array}{l}\text { Substantial financial } \\
\text { investment beginning in } \\
\text { the } 1980 \text { s } \\
\text { - support for public } \\
\text { institutions and } \\
\text { concessionaire } \\
\text { development and } \\
\text { governance } \\
\text { - technical assistance } \\
\text { - support for secondary- } \\
\text { level institutions }\end{array}$ & $\begin{array}{l}\text { Moderate investment } \\
\text { (beginning in the 1980s) } \\
\text { relative to government and } \\
\text { parastatals } \\
\text { - institution building/ } \\
\text { strengthening; } \\
\text { governance and } \\
\text { management capacity } \\
\text { building } \\
\text { - technical assistance } \\
\text { - assistance with } \\
\text { certification (channeled } \\
\text { through NGOs) }\end{array}$ & $\begin{array}{l}\text { Substantial financial } \\
\text { investment dating from } \\
\text { 1980s } \\
\cdot \text { technical training } \\
\cdot \text { governance and forest } \\
\text { management capacity } \\
\text { building } \\
\text { - infrastructure } \\
\text { development }\end{array}$ & $\begin{array}{l}\text { Substantial financial } \\
\text { investment dating from } \\
\text { early } 1990 \text { s } \\
\cdot \text { technical assistance } \\
\text { - capacity building } \\
\text { for governing and } \\
\text { managing wildlife } \\
\text { conservancies } \\
\text { - provision of } \\
\text { starting capital for } \\
\text { conservancies }\end{array}$ \\
\hline Public sector & $\begin{array}{l}\text { Financial investment } \\
\text { minor; most state } \\
\text { funds from donors and } \\
\text { development banks } \\
\text { - forest governance and } \\
\text { management capacity } \\
\text { building of public } \\
\text { institutions } \\
\text { - policy implementation } \\
\text { - enforcement }\end{array}$ & $\begin{array}{l}\text { Financial investment } \\
\text { significant; substantial } \\
\text { amounts from donors/ } \\
\text { development banks } \\
\text { - capacity building to } \\
\text { participate in parastatal } \\
\text { partnerships (1960s) } \\
\text { - parastatal investment } \\
\text { in institution building } \\
\text { (ejidos and ejidos unions), } \\
\text { infrastructure, and human } \\
\text { capital (1970s) } \\
\text { - development of CFEs } \\
\text { (1990s) } \\
\text { - management } \\
\text { and conservation } \\
\text { (1990s/2000s) }\end{array}$ & $\begin{array}{l}\text { Substantial financial } \\
\text { investment but much from } \\
\text { donors/development banks } \\
\cdot \text { technical training } \\
\text { - CFI forest governance } \\
\text { and forest management } \\
\text { capacity building } \\
\text { - infrastructure } \\
\text { development }\end{array}$ & $\begin{array}{l}\text { Substantial financial } \\
\text { investment, but } \\
\text { much from donors/ } \\
\text { development banks } \\
\text { - policy development } \\
\text { - mapping and } \\
\text { licensing of } \\
\text { conservancies } \\
\text { - awareness raising } \\
\text { about new rules } \\
\text { - training } \\
\text { - long-term planning } \\
\text { - } \text { staffing and vehicles }\end{array}$ \\
\hline
\end{tabular}


Table 1 (cont.). Investments subsequent to rights devolution.

\begin{tabular}{|c|c|c|c|c|}
\hline & Guatemala & Mexico & Nepal & Namibia \\
\hline $\begin{array}{l}\text { Community } \\
\text { forest } \\
\text { institutions }\end{array}$ & $\begin{array}{l}\text { Substantial financial } \\
\text { investment (relative } \\
\text { to revenues) as } \\
\text { concessionaires have } \\
\text { gained in competency } \\
\text { - capacity building to } \\
\text { manage/administer } \\
\text { concessions } \\
\text { - } \quad \text { forest management } \\
\text { plans } \\
\text { - value chain } \\
\text { development } \\
\text { - } \text { rights strengthening } \\
\text { - fire protection } \\
\text { - jobs for concessionaire } \\
\text { members and other } \\
\text { households } \\
\text { health and education } \\
\text { Secondary-level } \\
\text { institutions (the } \\
\text { Community Forest } \\
\text { Association of Petén } \\
\text { (ACOFOP) and Community } \\
\text { Enterprise of Forest } \\
\text { Services Ltd (FORESCOM)) } \\
\text { are key to acquiring } \\
\text { additional funding/ } \\
\text { expanding influence }\end{array}$ & $\begin{array}{l}\text { Substantial financial } \\
\text { investments (relative to } \\
\text { revenues) as CFls have } \\
\text { gained competency } \\
\text { - forest management plans } \\
\text { - value-chain } \\
\text { development/equipment } \\
\text { and facilities } \\
\text { - forest improvements/ } \\
\text { conservation } \\
\text { - jobs for community } \\
\text { members } \\
\text { - road infrastructure, } \\
\text { education, health } \\
\text { Numerous secondary } \\
\text { institutions (ejido unions, } \\
\text { joint venture associations) } \\
\text { Joint venture associations } \\
\text { between communities make } \\
\text { financial investments in } \\
\text { enterprise development and } \\
\text { public goods }\end{array}$ & $\begin{array}{l}\text { Substantial financial } \\
\text { investments (relative to } \\
\text { revenues) as CFIs have } \\
\text { gained competencies } \\
\text { - jobs for members } \\
\text { - } \quad \text { forest-based enterprises } \\
\text { - } \quad \text { forest management } \\
\text { plans } \\
\text { - forest protection/ } \\
\text { improvements } \\
\text { - roads, water, education, } \\
\text { health care } \\
\text { Federation of Community } \\
\text { Forest Users Nepal } \\
\text { (FECOFUN) plays a key } \\
\text { role in strengthening } \\
\text { community use rights to } \\
\text { forests and building CFE } \\
\text { capacity }\end{array}$ & $\begin{array}{l}\text { Substantial financial } \\
\text { investments (relative to } \\
\text { revenues) as CFIs have } \\
\text { gained competency } \\
\text { - job creation } \\
\text { - ecotourism and } \\
\text { conservation hunting } \\
\text { enterprises } \\
\text { - infrastructure } \\
\text { - education/health } \\
\text { care } \\
\text { - wildlife protection } \\
\text { management plans } \\
\text { Lacks a national } \\
\text { conservancy association; } \\
\text { regional conservancy } \\
\text { associations are } \\
\text { members of Namibian } \\
\text { Association for CBNRM } \\
\text { Support Organisations } \\
\text { (NACSO) }\end{array}$ \\
\hline Private sector & $\begin{array}{l}\text { Limited financial } \\
\text { investment thus far, but } \\
\text { partnerships between } \\
\text { development banks } \\
\text { and commercial banks } \\
\text { providing credit to forest } \\
\text { enterprises are beginning } \\
\text { to emerge }\end{array}$ & $\begin{array}{l}\text { Publicly subsidized } \\
\text { logging company- } \\
\text { community partnerships } \\
\text { dating back to } 1960 \mathrm{~s} \\
\text { invested in capacity } \\
\text { of communities } \\
\text { to participate in } \\
\text { partnerships } \\
\text { - Parastatal investments } \\
\text { in infrastructure and } \\
\text { human capital in 1970s } \\
\text { provided foundation } \\
\text { for community forest } \\
\text { enterprises to emerge } \\
\text { Community-buyer } \\
\text { alliances are common }\end{array}$ & $\begin{array}{l}\text { - Limited external private } \\
\text { sector involvement. } \\
\text { Small and medium- } \\
\text { scale forest enterprises } \\
\text { have begun to invest } \\
\text { in timber processing, } \\
\text { tourism activities, } \\
\text { NTFP processing and } \\
\text { marketing. } \\
\text { A blended finance } \\
\text { program involving } \\
\text { multiple development } \\
\text { banks, the Nepali } \\
\text { government, and } \\
\text { communities has } \\
\text { recently emerged }\end{array}$ & $\begin{array}{l}\text { - Strong private } \\
\text { sector involvement. } \\
\text { Numerous joint } \\
\text { venture agreements } \\
\text { exist between } \\
\text { conservancies } \\
\text { and private sector } \\
\text { operators } \\
\text { An emerging } \\
\text { alternative source } \\
\text { of revenue is a } \\
\text { Wildlife Credits and } \\
\text { Incentives stream, } \\
\text { linking conservancy } \\
\text { performance to } \\
\text { investment }\end{array}$ \\
\hline NGOs & $\begin{array}{l}\text { Donors typically channel } \\
\text { assistance to CFIs through } \\
\text { NGOs } \\
\text { - forest management } \\
\text { skills } \\
\text { - forest management } \\
\text { plans } \\
\text { - Forest Stewardship } \\
\text { Council (FSC) } \\
\text { certification } \\
\text { - business management } \\
\text { trainingvalue chain } \\
\text { development (timber } \\
\text { and non-timber forest } \\
\text { products (NTFPs)) } \\
\text { policy reform } \\
\text { advocacy }\end{array}$ & $\begin{array}{l}\text { Donors typically channel } \\
\text { assistance to CFIs through } \\
\text { NGOs } \\
\text { - forest management plans } \\
\text { - forest management skills } \\
\text { - FSC certification } \\
\text { - business management } \\
\text { - training } \\
\text { - } \text { value chain development }\end{array}$ & $\begin{array}{l}\text { Donors typically channel } \\
\text { assistance to CFIs through } \\
\text { NGOs } \\
\text { - forest management } \\
\text { plans } \\
\text { - forest management skills } \\
\text { - FSC certification for } \\
\text { NTFPs } \\
\text { - financial skills/business } \\
\text { - management training } \\
\text { NTFP value chain } \\
\text { - development } \\
\text { policy reform advocacy }\end{array}$ & $\begin{array}{l}\text { Consortium of local } \\
\text { and international NGOs } \\
\text { founded the Namibian } \\
\text { Association for CBNRM } \\
\text { Support Organisations } \\
\text { (NACSO) } \\
\text { - legal assistance } \\
\text { for conservancy } \\
\text { registration and joint } \\
\text { venture agreements } \\
\text { - wildlife monitoring/ } \\
\text { wildlife damage } \\
\text { insurance systems } \\
\text { - financial and } \\
\text { administrative skills } \\
\text { training } \\
\text { veld products value } \\
\text { chain development }\end{array}$ \\
\hline
\end{tabular}




\section{Discussion}

Proposition 1 - Barriers to commons-based investment are not insurmountable and investment in community-owned resources is taking place. External investment has come primarily from donors and governments, but private sector investment is increasing.

- Donors, including providers of official development assistance (ODA) and development finance institutions (DFIs), appear to be the most significant investors in community-held resources.

- Domestic public sector support varies. Government investment was strong in Mexico, Namibia and Nepal, but relatively weak in Guatemala. In Namibia and Nepal, a large portion of government investment is acquired from donor agencies.

- $\quad$ Limited private investment is occurring in all four cases, with assurance provided in different ways. Joint ventures are common in Namibia and Mexico. Simple lease or off-take agreements with communities are seen in Nepal and Namibia. Blended financing, in which a development bank or donor may assume some of the first loss risk on a loan, is increasingly being used in Nepal and Guatemala.

Proposition 2 - Investment readiness requires that prospective investors and investees have assurance that each party's obligations will be honored. Each sector takes on specific roles and responsibilities for mitigating risk. Investment readiness develops over time and in stages as levels of assurance increase.

- Donor and governmental investments were critical for building CFI capacity early on in areas such as governance, financial literacy, administration, business plan development and forest management.

- Donors often channeled funds through NGOs or consultants to build capacity, broker deals between investors and communities, and provide assurance to investors that they would see desired returns.

- The formation of new partnerships was instrumental in the emergence of financially viable CFIs. Assistance from NGOs enabled CFIs to obtain Forest Stewardship Council (FSC) certification for timber in Guatemala and Mexico and for NTFPs in Nepal. In Namibia, private sector partners have provided training that has enabled conservancies to achieve international hospitality and tourism standards.

- National-level associations have played a key role in enabling financially viable CFIs to emerge. Through secondary-level organizations, CFIs have advocated successfully for policy reforms that have improved enabling conditions for community-based enterprises.

- New practices around finance mechanisms are being experimented with and then institutionalized.

- The Namibian Association of CBNRM Support Organisations (NACSO) has created a conservation fund to attract funds from a variety of sources and channel them to conservancies.
- In Mexico, some CFIs have developed innovative intercommunity associations that enable them to achieve economies of scale.

- Guatemalan forest concessionaires are experimenting with blended finance mechanisms involving a combination of multilateral funding and bank credit.

- In Nepal, some CFls have developed self-financing mechanisms such as stratified membership fees to cover training and equipment costs.

Our results support Kluvánková et al.'s (2018) proposition that community forest enterprises are part of a broader dynamic social innovation system. The social innovation system is triggered by the devolution of rights to communities. Investments materialize in phases, with levels of assurance and needs changing as the system evolves (Figure 2). Figure 3 depicts our revised TOC diagram, which reflects the phased nature of the social innovation system.

Proposition 3 - Community rights have fostered investment that recognizes the social character of commons ownership and delivers environmental and social returns, as well as profits.

- CFls emphasized creating employment opportunities even at the expense of some loss of financial competitiveness. They preferentially provided part-time employment to all members of the community who would like to work, rather than offering full-time employment to a select few.

- CFls have taken on some governmental functions, specifically the provision of public goods such as roads, schools and health clinics.

- CFIs typically make investments aimed at enhancing forest (or wildlife) productivity, investments which have tended to yield positive environmental outcomes.

\section{Conclusions}

We note three key features from the cases that can inform policies and programs aimed at supporting investments in CFls.

- Different sources of financial investment enter at different stages. Public sector and donor investments are critical in the first phase when risks to investors are highest. They continue in phase two, when risks and transaction costs, although reduced, remain high. Private sector financial investment ramps up in phase three, once risks and transaction costs are reduced.

- The types of investments required change as the social innovation system moves into each new phase. Enabling investments are needed initially to establish the social infrastructure required for communities to actualize their rights. During phase two, enabling investments continue to be important but asset investments gain in significance as they increase the likelihood that CFIs will deliver an adequate supply of products with the desired qualities. In phase three, asset investments begin to dominate. 
Phase 1 - Investment in rights devolution and governance institutions

- Phase one is characterized by investments in effectuating rights devolution and facilitating the emergence of CFIs that can effectively govern forest or other resource commons.

- The state and donors are the dominant external investors during this phase, with local and international NGOs serving primarily as intermediaries between CFIs and state agencies and between CFIs and donors.

- Barriers to investment in enterprises associated with CFIs typically exist and need to be overcome.

- During this phase, investments fall into Elson's (2010) "enabling investments" category.
Phase 2 - Investment in governance and technical capacity

- Focus is on building the CFIs' administrative and organizational management capacity. This together with technical capacity building and associated management activities improves the natural resource base.

- Additional investments support communal enterprises in established markets such as timber and tourism.

- Donors and the state continue to be the dominant external investors, and NGOs continue to function as intermediaries.

- CFIs, often with NGO support, establish federations that represent CFI interests, advocate for policy reforms, and help CFIs realize economies of scale.

- Investments fall primarily into the enabling investment category, but some asset investments are made.

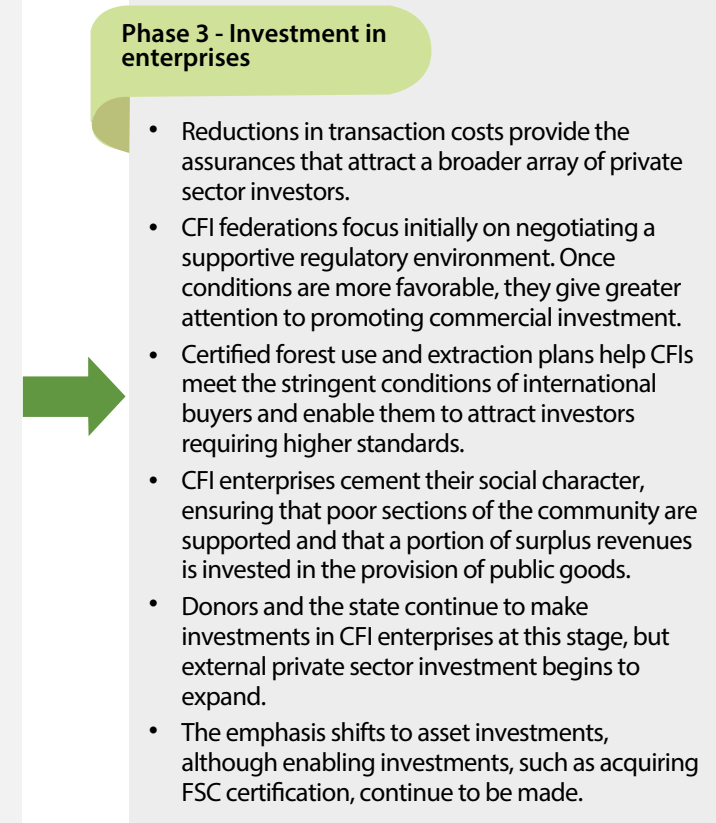

Figure 2. Phases of investment in CFIs.

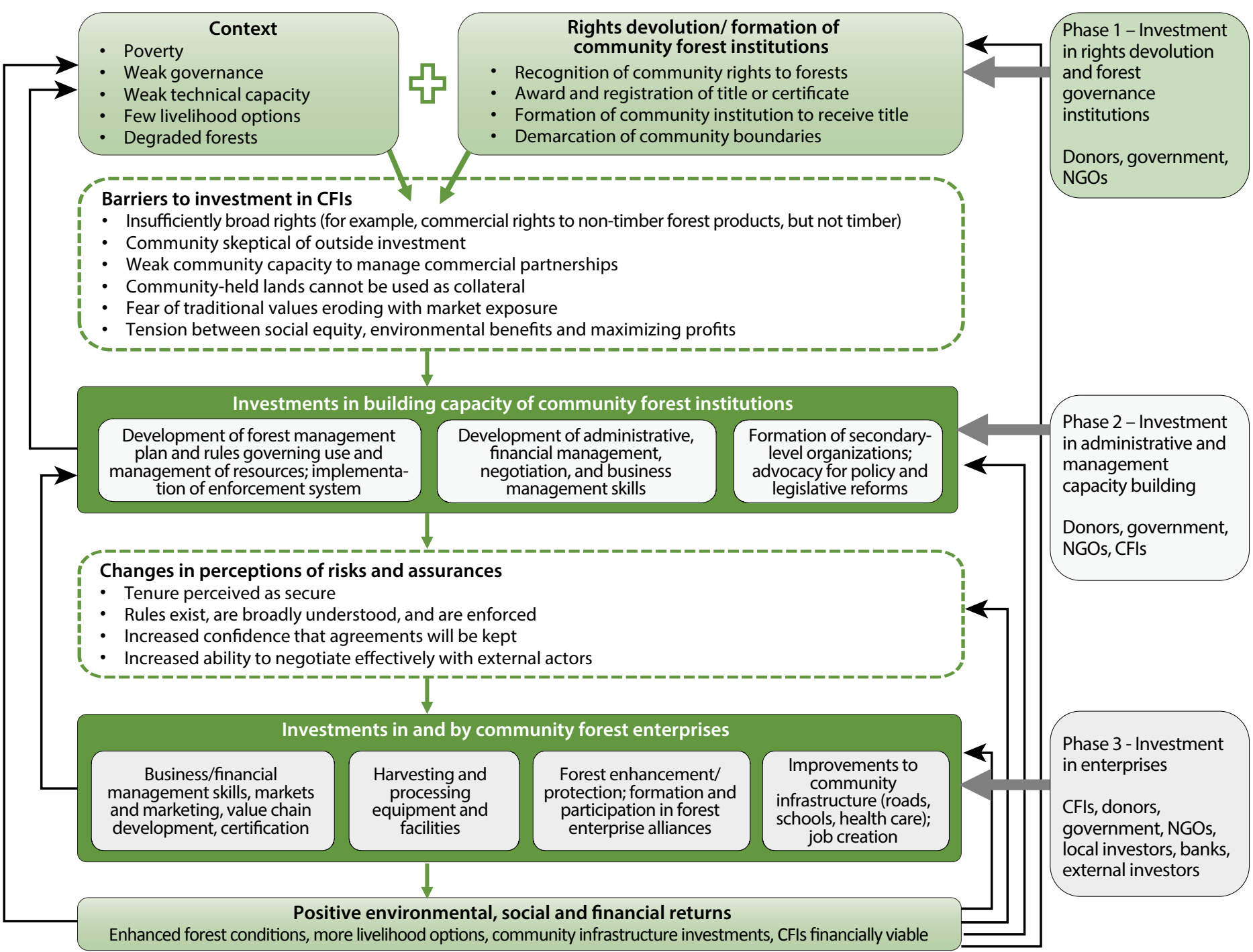

Figure 3. Adapted theory of change linking rights devolution, investments, and outcomes. 
- The evolution of investments in CFIs is iterative. The outcomes of the initial enabling investments alter the context and catalyze the need for asset investments, as well as additional enabling investments. Through a constant process of learning and adapting, CFls build the confidence of their members and external investors that they can deliver adequate financial returns.

Communities, governments and the private sector have to be viewed by all parties as co-equal partners in social innovation systems that create and sustain the conditions that enable community-based social enterprises, serving a variety of environmental, social and economic goals. A shared understanding of the systemic character of innovation processes cannot always be taken for granted, and some parties, especially in government and the private sector, do not understand that fundamental, permanent changes in some of their own policies and practices are also required. Forest agencies need to dial back their forestuse enforcement functions and invest more in protecting community rights and building local organizational capacity. Private businesses need to be willing to accommodate the social welfare and employment aims of CFIs. Additional research is needed on the sources, mechanisms, volume and direction of investment in community-managed resources that can create the action space for social innovation. Given the changing capital needs of CFIs as they grow, we argue that it is important to focus research on gaining a better understanding of their financing options and investment potential at different stages of their development.

\section{Acknowledgments}

Funding from CGIAR Research Program on Policies, Institutions and Markets (PIM) led by the International Food Policy Research Institute (IFPRI) and the Center for International Forestry Research (CIFOR) supported this work.

This info brief was developed from a paper presented at the World Bank 2018 Land and Poverty Conference: Land Governance in an Interconnected World. Washington D.C. 19-23 March 2018. 07-07: Community Rights for Environmental Benefit by Lawry S, Gynch S, Monterroso I and Adhikary A. 2018. Common benefits: How community tenure is facilitating investment in the commons for inclusive growth.

\section{References}

Ambrose-Oji B, Lawrence A and Stewart A. 2015. Community based forest enterprises in Britain: two organising typologies. Forest Policy and Economics 58:65-74.

Baynes J, Herbohn J, Smith C, Fisher R and Braye D. 2015. Key factors which influence the success of community forestry in developing countries. Global Environmental Change 35:226-238.
Bhandari PKC, Bhusal P, Paudel G, Upadhyaya CP and Chhetri BBK. 2019. Importance of community forestry funds for rural development in Nepal. Resources 8(2):85. doi:10.3390/ resources 8020085

Bray D and Merino L. 2002. The rise of community forestry in Mexico: History, concepts, and lessons learned from twenty years of community timber production (p. 133). Project Report. México, D.F.: Ford Foundation.

Carrillo-Anzures M, Flores E, Torres Rojo J, Sangerman-Jarquín D, González L and Buendía E. 2017. Characterization of forest producers in 12 states of the Mexican Republic. Revista Mexicana de Ciencias Agrícolas 8(7):1561-73.

Cronkleton P, Bray DB and Medina G. 2011. Community forest management and the emergence of multi-scale governance institutions: lessons for REDD+ development from Mexico, Brazil and Bolivia. Forests 2:451-73.

Dasgupta P. 2005. Common property resources: Economic analytics. Economic and Political Weekly 40(16):1610-1622.

Elson D. 2012. Guide to investing in locally controlled forestry. Growing forest partnerships in association with FAO, IIED, IUCN, The Forests Dialogue and the World Bank. London, UK: International Institute for Environment and Development.

Fellnhofer K. 2015. Literature review: investment readiness level of small and medium sized companies. International Journal of Managerial and Financial Accounting 7(3/4): 268-84.

Foundjem-Tita D, Duguma LA, Speelman S and Piabuo SM. 2018. Viability of community forests as social enterprises: a Cameroon case study. Ecology and Society 23(4):50. doi. org/10.5751/ES-10651-230450

Hewitt D and Castro Delgadillo M. 2009. Key factors for successful community-corporate partnerships - results of a comparative analysis among Latin American cases. Richmond, Vermont, USA: Rainforest Alliance.

Kluvánková T, Brnkalákova S, Špaček M, Slee B, Nijnik M, Valero D, Miller D, Bryce R, Kozova M, Polman N, Szabo T and Gežík V. 2018. Understanding social innovation for the wellbeing of forest-dependent communities: A preliminary theoretical framework. Forest Policy and Economics 97:163-74

Lawry S, Samii C, Hall R, Leopold A, Hornby D and Mtero F. 2017. The impact of land property rights interventions on investment and agricultural productivity in developing countries: a systematic review. Journal of Development Effectiveness 9(1):61-81.

Mason C and Kwok J. 2010. Investment readiness programmes and access to finance: a critical review of design issues. Local Economy 25(4):269-92.

[MET/NACSO] Ministry of Environment and Tourism/ Namibian Association of CBNRM Support Organisations. 2018. The state of community conservation in Namibia - a review of communal conservancies, community forests and other CBNRM activities (Annual Report 2017). Windhoek, Namibia: MET/NACSO. 
Naidoo R, Weaver C, Diggle RW, Greenwell M, Stuart-Hill G and Thouless C. 2016. Complementary benefits of tourism and hunting to communal conservancies in Namibia. Conservation Biology 30(3):628-38.

Paudel NS, Monterroso I and Cronkleton P. 2012. Secondary level organisations and the democratisation of forest governance: Case studies from Nepal and Guatemala. Conservation and Society 10(2):124-135.

Polman N, Slee W, Kluvánková T, Dijkshoorn M, Nijnik M, Gezik $\checkmark$ and Soma K. 2017. Classification of Social Innovations for
Marginalized Rural Areas, Deliverable 2.1, Social Innovation in Marginalised Rural Areas (SIMRA). Brussels, Belgium: European Union Framework Programme Horizon 202. pp. 32.

Radachowsky J, Ramos VH, McNab R, Baur EH and Kazakov N. 2012. Forest concessions in the Maya Biosphere Reserve, Guatemala: A decade later. Forest Ecology and Management 268:18-28.

Wily LA. 2018. Collective land ownership in the 21st century: Overview of global trends. Land 7(2):68, https://doi. org/10.3390/land7020068

Contact: Steven Lawry (s.lawry@cgiar.org)

\begin{tabular}{|l|l} 
RESEARCH & The CGIAR Research Program on Policies, Institutions, and Markets (PIM) leads action-oriented research \\
PROGRAM on & $\begin{array}{l}\text { Policies, } \\
\text { Institutions, } \\
\text { Insuip decisionmakers with the evidence required to develop food and agricultural policies that better } \\
\text { and Markets } \\
\text { serve the interests of poor producers and consumers, both men and women. PIM combines the resources } \\
\text { of CGIAR centers and numerous international, regional, and national partners. The program is led by the } \\
\text { International Food Policy Research Institute (IFPRI). www.pim.cgiar.org }\end{array}$
\end{tabular}

